\title{
New record of the glassfrogs Hyalinobatrachium cappellei (Van Lidth de Jeude, 1904) and Cochranella adenocheira Harvey and Noonan, 2005, (Anura: Centrolenidae) in Volta Grande do Xingu, north Pará state, Brazil
}

\author{
Oliveira, RM. ${ }^{a *}$, Penhacek, M. ${ }^{a}$, Wronski, L. ${ }^{a}$, Xavier, J. ${ }^{a}$ and Vaz-Silva, W. ${ }^{b}$ \\ a'Biota Projetos e Consultoria Ambiental Ltda., Rua 86 C, 64, CEP 74083-360, Goiânia, GO, Brazil

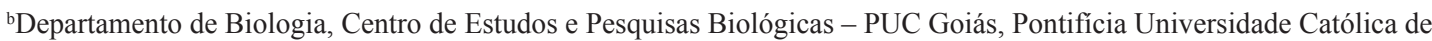 \\ Goiás - UCG, Rua 235, 40, Bloco L, Setor Universitário, CEP 74605-010, Goiânia, GO, Brazil \\ *e-mail: renan29_oliveira@yahoo.com.br
}

Received: June 2, 2014 - Accepted: December 11, 2014 - Distribuited: August 31, 2015

(With 2 figures)

The Neotropical family Centrolenidae Taylor, 1951, comprises species popularly known as glassfrogs, which are found from Central America to south Brazil, occurring in the Andes and forests in central Brazil (Guayasamin et al., 2009; Cintra et al., 2013; Frost, 2014). Currently, 12 genera and 149 species are known (Pyron and Wiens, 2011; Frost, 2014), of which 11 occur in Brazil (Frost, 2014; Segalla et al., 2014).

Hyalinobatrachium cappellei (van Lidth de Jeude, 1904 ) is a medium size glassfrog (adult males SVL $=18.6$ $24.9 \mathrm{~mm}$ ), described from only one individual collected on the Saramacca expedition in Suriname (van Lidth de Jeude, 1904; Castroviejo-Fisher et al., 2011). This species occurs from Venezuela to French Guiana, through Guiana Shield (Castroviejo-Fisher et al., 2011), with recent new records in Brazilian Amazonia by Simões et al. (2012) in Amazonas state, and by Rodrigues et al. (2010) (as $H$. crurifasciatum Myers and Donnely, 1997, junior synonym) and Noronha et al. (2012) in Mato Grosso state. Morphological characters (snout truncated in dorsal and lateral views, tympanic membrane and annulus not appreciable in life), call parameters (dominant frequency and call structure), and molecular evidence allows differentiation of $H$. cappellei from others in the genus that occurs in South America (Castroviejo-Fisher et al., 2009, 2011).

Cochranella adenocheira Harvey and Noonan, 2005 is a medium size glassfrog (holotype male $\mathrm{SVL}=22.4 \mathrm{~mm}$ ) described from individuals collected in the Parque Noel Kempff Mercado, Santa Cruz, Bolívia. The species occurs in Bolivia (type locality) and Brazil, in the south of Mato Grosso, south of Pará and north of Rondônia State (Toledo et al., 2009; Oliveira et al., 2012). The species is allocated into $C$. ocellata species group according to the original description, which is characterised by a truncated snout and smooth dermal folds. The colour of visceral and parietal peritoneum, dorsal coloration, presence of tarsal and ulnar folds, absence of supernumerary tubercles, and size of the digital pads, distinguish $C$. adenocheira from the other species of the C. ocellta species group (Harvey and Noonan, 2005).

In March 2014, during the Herpetofauna Monitoring Environmental Programme from UHE Belo Monte region (Altamira, Brasil Novo and Vitória do Xingu municipalities, northern Pará State), we found Hyalinobatrachium cappellei and Cochranella adenocheira individuals (Figure 1). One male of $H$. cappellei was recorded to aid in species determination. We used a Tascam DR-100 digital audio recorder with a unidirectional Yoga HT-81 microphone. Calls were analysed at a resolution of 16 bits and $48 \mathrm{kHz}$ sampling rate, mono channel using Raven Pro 1.3 (Cornell Lab of Ornithology, 2008) with a Fast Fourier Transformation of 256 points, $50 \%$ overlap for an entire call and Window Hamming. Terminology of temporal and acoustic parameters follows Heyer et al. (1990). Voucher specimens were deposited in Herpetological Collection from Universidade Federal de Goiás (ZUFG).

Many males of $H$. cappellei were found at night, calling in streams located inside the forest $\left(3^{\circ} 31^{\prime} \mathrm{S}\right.$ and $\left.51^{\circ} 40^{\prime} \mathrm{W}\right)$. They were perched on the underside of leaves (Figure 2a) overhanging streams. Several males were found calling on leaves containing egg clutches (Figure 2c), at 1-6 m height. Species identity was determined from behavioural, morphology and call character. One male was recorded and collected as voucher specimen (ZUFG 8477 , $\mathrm{SVL}=20.9 \mathrm{~mm})$.

The advertisement call $\left(\mathrm{N}=15\right.$, air temperature $=25.6^{\circ} \mathrm{C}$; air humidity $=88 \%$ ) of the recorded male is compatible with the description provided by Castroviejo-Fisher et al. (2011). The call is composed by a single multi-pulsed note, that presents frequency modulation, increasing and decreasing, giving the shape of a saw (CastroviejoFisher et al., 2011). The call duration range is $0.254-0.288 \mathrm{~s}$ $(0.278 \pm 0.0086 \mathrm{~s}, \mathrm{~N}=15)$ and dominant frequency $4306-4823 \mathrm{~Hz}$ $(4593 \pm 140 \mathrm{~Hz}, \mathrm{~N}=15)$.

Three individuals of $C$. adenocheira were found and collected as voucher specimens (ZUFG 8478, ZUFG 8479 and ZUFG 8480), but many others were heard in 
the study area. The specimens were found perched on the upper surface of leaves (Figure 2b), at $1.5 \mathrm{~m}$ height, in a flooded area associated with a stream inside a forest fragment ( $3^{\circ} 31^{\prime} \mathrm{S}$ and $\left.51^{\circ} 40^{\prime} \mathrm{W}\right)$.

This new data represents a new state record of $H$. cappellei in Pará sate, Brazil and extends C. adenocheira distribution about $800 \mathrm{~km}$ (approximate straight distance) northeast from Jacareacanga, the nearest record in Pará state.

The type locality of $H$. cappellei is not clear. Van Lidth de Jeude (1904) states that the holotype was "collected by the Saramacca-expedition" and in Castroviejo-Fisher et al. (2011) the type locality is "River Saramacca and neighbouring

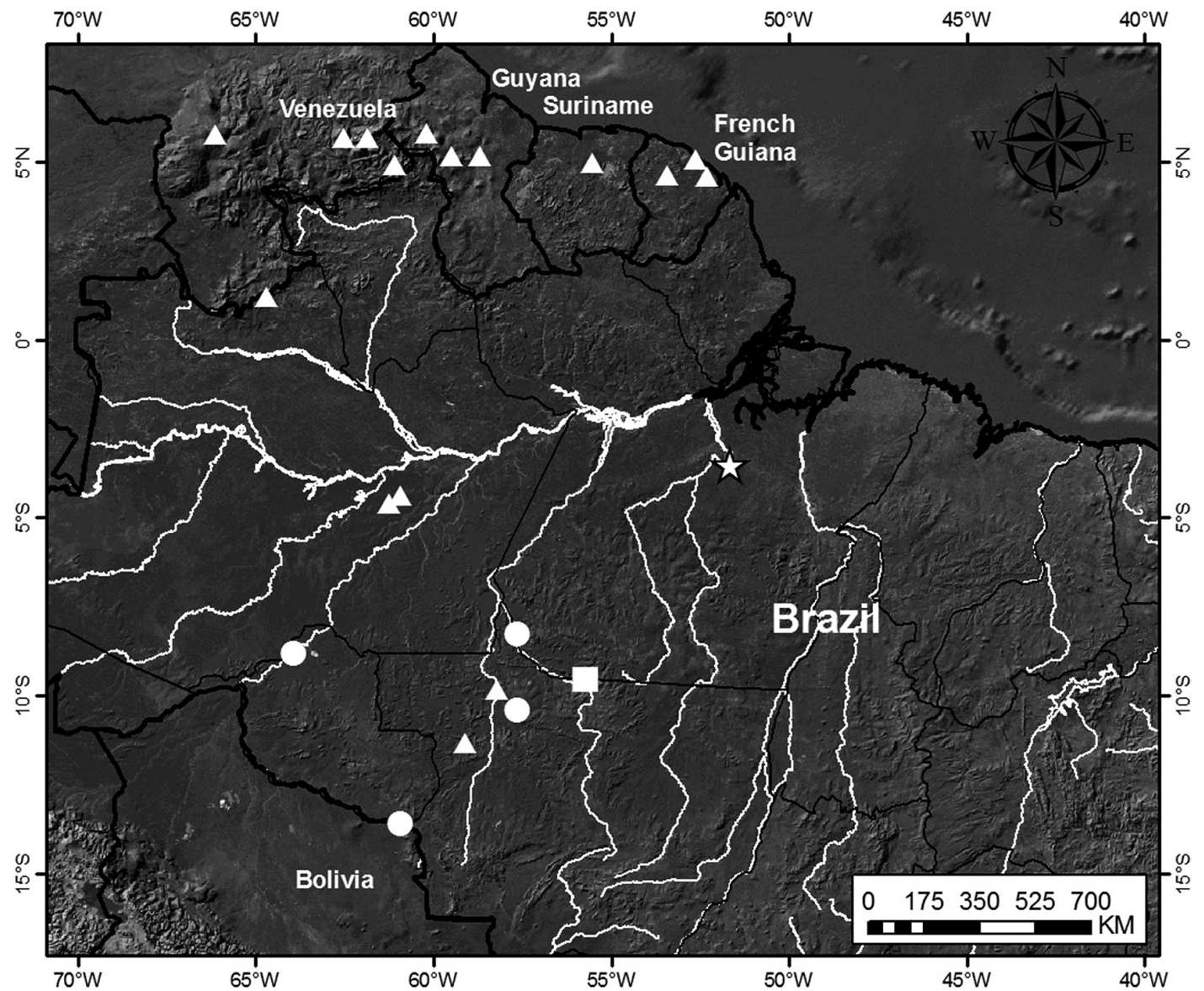

Figure 1. Known records of Hyalinobatrachium cappelei (triangles), Cochranella adenocheira (circles), common location for both species (square) and new data for both species (star) in Xingu River, Altamira, Pará, Brazil. Data source of H. cappellei distribution: Rodrigues et al. (2010), Castroviejo-Fisher et al. (2011), Noronha et al. (2012) and Simões et al. (2012). Data source of C. adenocheira distribution: Harvey and Noonan (2005), Toledo et al. (2009) and Oliveira et al. (2012).
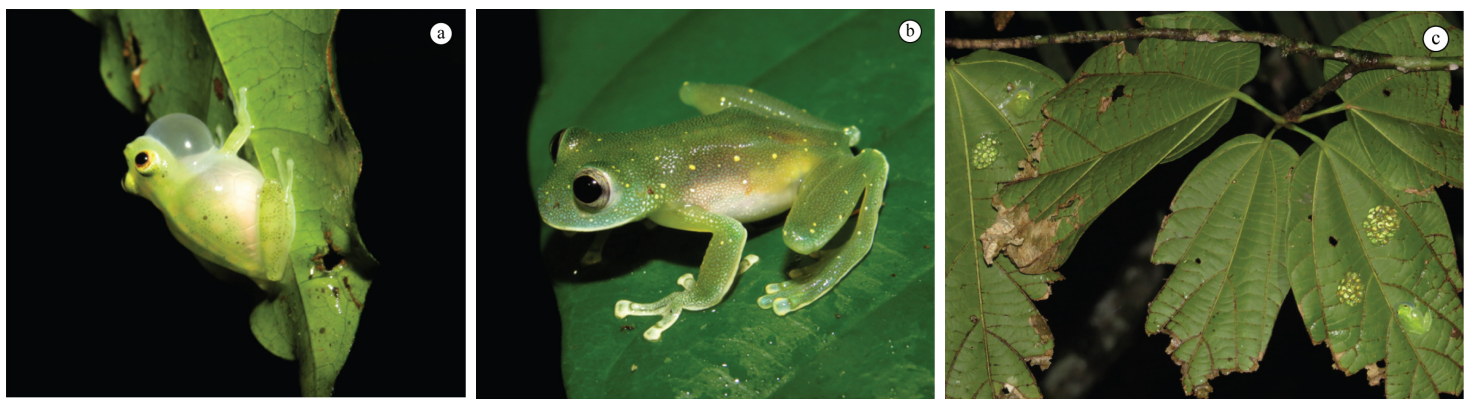

Figure 2. (a) Recorded male of Hyalinobatrachium cappellei (ZUFG 8477) calling on underside of leaf. Individual found March 2014 in Altamira, Pará. (b) Cochranella adenocheira (ZUFG 8478) collected in March 2014 in Altamira, Pará. (c) Two males of $H$. cappellei found calling on underside of leaves with egg clutches. 
areas, Suriname". The length of the river is approximately $460 \mathrm{~km}$, emerging from central Suriname and extending to the coast (Amatali, 1993). Thus, it is difficult to know where the exact type locality of the species is.

The recent records of Centrolenidae evidences that the occurrence area of glassfrogs in South America is probably underestimated and that future research will contribute to clarify the real distribution of the species.

\section{Acknowledgements}

We thank to Biota Projetos e Consultoria Ambiental, Leme Engenharia and Norte Energia for logistical and financial support. Rafael C. Teixeira, Julimar A. Oliveira and Samuel F. dos Anjos for assistance in the fieldwork. Fernando Estevam for help with the map. Specimens were collected under the permit 251/2013 issued by IBAMA.

\section{References}

AMATALI, MA., 1993. Climate and surface water hydrology. In OUBOTER, PE. The freshwater ecosystems of Suriname. Dordrecht: Springer Netherlands. p. 29-51.

CASTROVIEJO-FISHER, S., PADIAL, JM., CHAPARRO, JC., AGUAYO, R. and DE LA RIVA, I., 2009. A new species of Hyalinobatrachium (Anura: Centrolenidae) from the Amazonian slopes of the central Andes, with comments on the diversity of the genus in the area. Zootaxa, vol. 2143, p. 24-44.

CASTROVIEJO-FISHER, S., VILÀ, C., AYARZAGÜENA, J., BLANC, M. and ERNST, R., 2011. Species diversity of Hyalinobatrachium glassfrogs (Amphibia: Centrolenidae) from the Guiana Shield, with the description of two new species. Zootaxa, vol. 3132, p. 1-55.

CINTRA, CED., SILVA, HLR. and SILVA-JUNIOR, NJ., 2013. New state record of Vitreorana eurygnatha (Lutz 1925) (Anura: Centrolenidae) in Brazil. Herpetology Notes, vol. 6, p. 587-590.

Cornell Lab of Ornithology, Bioacoustics Research Program, 2008. Raven Pro: interactive sound analysis software. Ithaca. Version 1.3. Available from: <http://www.birds.cornell.edu/ raven>. Access in: 23 Mar. 2014.

FROST, DR., 2014. Amphibian Species of the World: an Online Reference. New York: American Museum of Natural History. Version 6.0. (November, 2014). Available from: <http://research.amnh. org/herpetology/amphibia/index.html>. Access in: 13 May 2014.

GUAYASAMIN, JM., CASTROVIEJO-FISHER, S., TRUEB, L., AYARZAGÜENA, J., RADA, M. and VILÀ, C., 2009. Phylogenetic systematics of glassfrogs (Amphibia: Centrolenidae) and their sister taxon Allophryne ruthveni. Zootaxa, vol. 2100, p. 1-97.

HARVEY, MB. and NOONAN, BP., 2005. Bolivian glass frogs (Anura: Centrolenidae) with a description of a new species from Amazonia. Proceedings of the Biological Society of Washington, vol. 118, no. 2, p. 428-441. http://dx.doi.org/10.2988/0006-324X( 2005)118[428:BGFACW]2.0.CO;2.

HEYER, WR., RAND, AS., CRUZ, CAG., PEIXOTO, OL. and NELSON, CE., 1990. Frogs of Boracéia. Arquivos de Zoologia, vol. 31, no. 4, p. 231-410.

MYERS, CW. and DONNELLY, MA., 1997. A tepui herpetofauna on a granitic mountain (Tamacuari) in the borderland between Venezuela and Brazil: report from the Phipps Tapirapecó Expedition. American Museum Novitates, no. 3213, p. 1-71.

NORONHA, JC., RODRIGUES, DJ., BARROS, AB. and ALMEIDA, EJ., 2012. New record and distribution map of Hyalinobatrachium cappellei (van Lidth de Jeude 1904) (Anura: Centrolenidae). Herpetology Notes, vol. 5, p. 467-468.

OLIVEIRA, USC., MENEGHELLI, D. and MESSIAS, MR., 2012. Amphibia, Anura, Centrolenidae, Cochranella adenocheira Harvey and Noonan, 2005: Distribution and geographic extension in the state of Rondônia, Brazil. CheckList, vol. 8, no. 1, p. 145-146.

PYRON, RA. and WIENS, JJ., 2011. A large-scale phylogeny of Amphibia including over 2800 species, and a revised classification of extant frogs, salamanders, and caecilians. Molecular Phylogenetics and Evolution, vol. 61, no. 2, p. 543-583. http://dx.doi.org/10.1016/j. ympev.2011.06.012. PMid:21723399.

RODRIGUES, DDJ., LIMA, MDM., MORAIS, DH. and KAWASHITA-RIBEIRO, RA., 2010. Amphibia, Anura, Centrolenidae, Hyalinobatrachium crurifasciatum Myers and Donnelly, 1997: First record from Brazil and geographic distribution map. CheckList, vol. 6, no. 3, p. 392-394.

SEGALLA, MV., CARAMASCHI, U., CRUZ, CAG., GRANT, T., HADDAD, CFB LANGONE, J. and GARCIA, PCA., 2014. Brazilian amphibians: list of species. Herpetologia Brasileira, vol. 3, no. 2, p. 37-48. Available from: $<$ http://www.sbherpetologia. org.br>. Access in: 11 Nov. 2014.

SIMÕES, PI., KAEFER, IL., GOMES, R., BITTIOLI, F. and PIMENTEL, AL., 2012. Distribution extension of Hyalinobatrachium cappellei (van Lidth de Jeude, 1904)(Anura: Centrolenidae) across Central Amazonia. CheckList, vol. 8, no. 4, p. 636-637.

TOLEDO, LF., ARAUJO, OGS., ÁVILA, RW., KAWASHITARIBEIRO, RA., MORAIS, DH. and CISNEROS-HEREDIA, DF., 2009. Amphibia, Anura, Centrolenidae, Cochranella adenocheira: distribution and range extension, Brazil. Check List, vol. 5, no. 3 , p. $380-382$.

VAN LIDTH DE JEUDE, TW., 1904. Reptiles and batrachians from Surinam. Notes from the Leyden Museum, vol. 25, p. 83-186. 